Part I - Conceptualizing the Power Dimensions of Securitization 


\section{Dynamics of Power in Securitization: Towards a Relational Understanding}

Andreas Langenohl

\section{Introduction}

This chapter presents a theoretical and conceptual reconstruction of understandings of power in current securitization studies. In the first part (sections 1 and 2), it argues that these understandings have to be approached against the background of all three major 'schools' in post-realist securitization studies that maintain a critical relation to realist International Relations (IR), and that conceptions of power crucially revolve around the question of how to conceptually situate the political in processes of securitization. In particular, this chapter will argue that the Copenhagen School's theorization of securitization provides the richest basis for this endeavor because it is based on the conception - perhaps implicit - that rescues power as a particular mode of the political for analysis.

This argument then provides the platform for the paper's second part (sections 3 and 4), which suggests a relational model of the power of securitization. Drawing on works in relational sociology, especially such by Norbert Elias, it proposes a distinction between the conditions that enable actors to engage in securitization (the power to securitize), and the different effects that these practices may have, including those that come as unintended consequences of securitization (the power of securitization). While acknowledging that these two parts of the paper may be read as forming different projects that both merit chapters of their own, I want to show that a discussion of current securitization studies' engagement with the question of power (and the absence thereof) actually invites a relational modelling of power dynamics in securitization.

\section{Current Securitization Studies: Three schools and their disputes}

This section introduces current securitization studies by way of what can be identified as their common genealogy, namely a critical questioning of 
assumptions regarding security in realist understandings of International Relations (IR). The three schools of securitization - "Copenhagen, Paris, Aberystwyth" as identified by Ole Wæver ${ }^{1}$ - regard themselves as critical interventions into realist and neo-realist theories of international relations, claiming the core of IR - that is, security - for alternative readings of security. In this, they also challenge the realist conception of power in IR as rational and utilitarian agency on the side of states and their elites, respectively. ${ }^{2}$ From the perspective of securitization, 'security' is not the natural prerogative and concern of states within an anarchic international system, but is rather claimed by political elites and other actors for the legitimation of political agency and supremacy.

At the same time, the three schools differ with respect to how exactly they reconstruct the logic of securitization. This section traces the major disputes in securitization studies, in particular the debates around the speech-act theoretical model of the Copenhagen School, the role of audiences in supporting or denying 'securitizing moves,' and attempts to include the dimension of routines and practices into the conceptualization of securitization. At stake in these discussions is, on the one hand, the effectiveness of securitization practices and, on the other hand, the ways that securitization is imbricated with strategies of implicit or explicit authorization and legitimation. With effectiveness and authorization/legitimation being two conceptual core components of political power as commonly understood, it is surprising that the debates in securitization studies have so far mostly refrained from dedicating conceptual attention to 'power' as a major component in the theoretical genealogy of securitization studies. This prepares for the discussion in Part II, which is dedicated to a theoretical and conceptual reconstruction of understandings of power in current securitization studies.

\section{1 "Copenhagen, Paris, Aberystwyth": Three interventions into realist International Relations}

The field of current security studies is characterized by a multitude of approaches that multiplied with the advent of non-realist security studies in

1 Wæver 2004, 2015, pp. 92-93.

2 Cf. Lipschutz 1995, Der Derian 1995. 
the 1980s. ${ }^{3}$ Starting with the Copenhagen School of Security Studies (CS), since the end of the systems confrontation between liberal-capitalist West and state-socialist East, a number of approaches have formed whose aim it is to articulate alternatives to the dominant realism in International Relations (IR). While realism has meanwhile differentiated itself into competing sub-approaches such as 'neorealism' or 'neoliberalism', ${ }^{4}$ it is still, broadly put, characterized by the conviction that polities (that is, states) have 'natural' security interests (often named raison d'état), that these interests tend to conflict with each other, and that such conflicts take place within a normatively largely unregulated, in fact 'anarchic' interstate system. By way of contrast, critical interventions into realist approaches proceed from the assumption that security interests are neither given nor naturally coupled to a polity's condition of existence or existential threats, but that they are politically, socially and culturally constituted. In other words, security is the outcome of processes termed securitization. Not least, this approach promises to yield more historical context to security studies, highlighting the historical conditions under which particular policy fields or societal, economic and cultural concerns become subject to securitization. ${ }^{5}$

The inner differentiation of this branch of security studies - which one might call constitutive-theoretical securitization studies as they are all interested in the ways that security concerns become constituted through actors, discourses and practices - has been quite complex since the early 1990s. Two 'schools' of securitization studies - the CS and the 'Aberystwyth' or 'Welsh School' (WS) - emerged virtually simultaneously, at that time not entertaining many interconnections. Later, the so-called Paris School (PS) emerged, partly in critical appreciation of major conceptual elements of the CS. These debates have been shot through with broader theoretical referentialities, and have been characterized differently by the protagonists in the debate. For instance, Balzacq opposes two broad currents in securitization studies, namely 'philosophical' and 'sociological' approaches, whereby he attributes the philosophical register to the CS (because of their alleged clinging to a universalist speech-act theoretical model of securitization) and reserves the sociological register for the PS, stressing social and political conditions that determine the effectiveness of

3 Wæver 2004.

4 Cf. Jahn 2012, pp. 20-23.

5 Buzan \& Wæver 2009; Buzan 2016. 
securitizing practices. ${ }^{6}$ Buzan names feminism, constructivism, poststructuralism and postcolonial theory as major distinctions in current securitization studies that differentially rely on theoretical resources that combine an emphasis on the constitution of security with aspects of hierarchization and marginalization of subject positions. ${ }^{7}$

Here I want to briefly characterize the three schools, for introductory purposes. The CS, as already mentioned, fashions a speech-act theoretical model of securitization, according to which political actors label certain political, social, cultural or economic problems as existential threats to the existence and survival of the polity. ${ }^{8}$ The underlying speech-act theory is borrowed from Austin, ${ }^{9}$ and thus can be categorized as a linguistic-pragmatic theory. According to this theory, securitizing speech acts invoke a semantic repertoire, the so-called "grammar of security", ${ }^{10}$ that declares a problem as exceptional. Thus, its handling is made the prerogative of a centralized authority (usually the government) which is thus legitimized to suspend the normal checks and balances of political conduct. The PS, distancing itself from the CS's preoccupation with the speech-act, has been more interested in practices of securitization that change the conduct of social, political, economic and military affairs with the aim to fight threats. These practices usually operate beyond the level of publicity associated with political speech-acts, and are typically engaged in by experts who often make use of a professionalist, as opposed to political, type of legitimation. ${ }^{11}$ Finally, the WS, which has had some repercussions in feminist and postcolonial securitization theory, is based on a normative refutation of the state's claim to the security prerogative, arguing that security ought to relate to individuals, social groups and populations, whereas the state ought to be relegated to a purely instrumental role with respect to achieving such security. ${ }^{12}$ Security is thus associated with the emancipa-

6 Balzacq 2011.

7 Buzan 2016, pp. 128-129.

8 Wæver 1995, 1996; Buzan et al. 1998.

9 Austin 1976.

10 Buzan et al. 1998, p. 33.

11 Balzacq 2005, 2011; Bigo 2006; Leander 2010.

12 This redefinition of security concerns as related to social processes and conditions of participation is also reflected in more recent studies on changing 'cultures of security', like the extension of classically state-centered security concerns to the realm of so-called 'human security' (cf. Daase 2011, 2012), however, without the normative ambition that is characteristic of the WS. 
tion of individuals and peoples from oppressive state apparatuses. It is the express aim of the WS to refute realist IR, which is denounced to be obsessed with questions of the distribution of power among states, and to work toward a normative paradigm shift, that is, toward a notion of security informed by moral philosophy. ${ }^{13}$

In the following subsections, I will discuss some crucial issues regarding the interrelationship of these three schools as well as view them comparatively in greater detail, in order to prepare the later discussion of the implications of securitization processes regarding power dynamics in securitization. It is thereby useful to start out with a debate that has characterized in particular the interrelation between the CS and the PS, while the WS, which has been less present in the mainstream debates, will be given less attention.

\subsection{The 'audience' disputes}

The Copenhagen School's speech-act theoretical model of securitization implies audience conceptually in the performativity of the speech-act, and thus does not have to address the presence or absence of concrete audiences. According to Vuori, this limitation of the securitization move to its nucleus, the speech-act, is a strength of the CS because it is unambiguously constructivist: "Thus, the core of securitization theory is the intersubjective establishment of a security status for an issue. This core is not concerned with threat perceptions, or whether something is really a threat, nor is it concerned with security measures". ${ }^{14}$ The CS approach thus opts for a constitutive-theoretical variant of securitization theory that depicts the ultimate process of securitization in a speech act that conjures up a "grammar of security", ${ }^{15}$ whereby the notion of 'grammar' is deliberately used in the speech-act theoretical sense, namely as forming the 'felicity conditions' of a performative speech-act of securitization. Thus, Vuori's argument is that through the speech-act theoretical architecture of the "securitising move", 16 the departure from realist or substantialist notions of security can be accomplished most radically and decisively.

13 Booth 1991.

14 Vuori 2011, p. 136.

15 Buzan et al. 1998, p. 33.

16 Id., p. 25. 
From this perspective, the CS embeds itself within the much grander horizon of the linguistic turn (cf. Bachmann-Medick 2010), setting out to challenge any understanding that security refers to something ontologically given. Accordingly, it has been categorized as a theory dedicated to the analysis of security as a "self-referential practice" by Thierry Balzacq, its most ardent critic. ${ }^{17}$ However, the CS is not the only theoretical strand of securitization studies which opposes any substantialist understanding of security with an emphasis on the self-referentiality of security. Sharing the interest in the symbolic constitution of 'security', but rejecting the route via speech-act theory, Jef Huysmans holds that "[s]ecuritisation is not a speech act but a multidimensional process in which skills, expert knowledge, institutional routines as well as discourses of danger modulate the relation between security and freedom". ${ }^{18}$ In earlier works, Huysmans had suggested a discursive understanding of securitization, according to which the 'content' of security consists in "an ensemble or rules that is immanent to a security practice and that defines the practice in its specificity (Foucault, 1969: 63): I will use the Foucaultian concept 'discursive formation' to refer to this ordering logic which the signifier articulates." 19 Like the CS, Huysmans proceeds from a self-referential model of the practice of securitization, and also from the (historical) preexistence of a semantic structure to which securitizing acts make reference (called 'grammar' in the CS and 'discursive formation' by Huysmans). Yet unlike the CS, he does not see this self-referentiality grounded in the performativity of a speech-act but in the reproduction of a discourse through the practices it organizes.

As mentioned, Thierry Balzacq proved to be the strongest critic of the self-referential model of securitization. In 2005, he presented a detailed critique of the CS, arguing that it had appropriated Austinian speech-act theory in a one-sided manner. According to this critique, the CS collapses Austin's complex theoretical edifice of the performativity of speech-acts into only one of its aspects, namely that of 'illocution', that is, the capacity of certain speech acts to bring about a new status of social affairs by dint of their very utterance (which presupposes that the securitizing actor is socially authorized to perform the act). This comes at the expense of the aspect of 'perlocution', which regards reactions of addressees of that speech-

17 Balzacq 2005, p. 177.

18 Huysmans 2006a, p. 153, as quoted in Vuori 2011, p. 159.

19 Huysmans 1998, pp. 232-233. 
act as crucial conditions of its performativity, or empirical effectiveness. ${ }^{20}$ From this point of view, the response of 'audiences' to the securitizing move is thus of utmost importance for the empirical reconstruction of the speech-act's effectiveness. At the same time, Balzacq retained the importance given by both the CS and Huysmans to the "semantic repertoire of security [as] a combination of textual meaning - knowledge of the concept acquired through language (written or spoken) - and cultural meaning knowledge historically gained through previous interactions and situations. Taken together, these two kinds of meanings form a frame of reference through which security utterances can be understood". ${ }^{21}$ This "semantic repertoire" figured under the term of "context". In later works, Balzacq, while retaining the focus on the significance of audience responses to securitizing moves, enlarged his context model by non-discursive dimensions, in particular, "the dispositif, that is, a constellation of practices and tools".22

Since Balzacq's interventions, the notions of 'audience' and 'context' have been subjected to much differentiation against the background of manifold empirical studies, that is, they are used in order to differentiate empirical accounts of successful, or on the contrary failing, practices of securitization. ${ }^{23}$ The three texts mentioned in parenthesis are indicative of how the audience postulate has been taken up and differentiated into very different directions and in conversation with different strands in International Relations, the social sciences and the study of culture more broadly. For instance, Mark B. Salter conducts a "dramaturgical" analysis of air transport security in Canada which conceptually relates to Goffman's theatrical model of social encounters, underscoring the argument that the audience must cooperate in any actor's securitizing move for it to be persuasive and hence effective. ${ }^{24}$ Holger Stritzel presents an "intertextual" analysis of the securitization of organized crime in the U.S., where "discourse" is seen as an aspect of the social and securitizing acts are reconstructed with respect to how they situate themselves within a discursive structure encompassing more than just security-related discourses. ${ }^{25}$ This approach,

20 Balzacq 2005, pp. 174-178.

21 Id., p. 183.

22 Balzacq 2011, p. 3.

23 Salter 2008; Stritzel 2012; Senn 2016.

24 Salter 2008, p. 321.

25 Stritzel 2012, p. 549. 
although insisting on the audience's function in authorizing securitizing actors, itself relates to audience responses proper only indirectly, instead depicting the persuasive strength of securitizing moves in their ability to involve various discourses. Even more radically, Martin Senn's "rhetorical" analysis of post-Cold War nuclear arms securitization, ${ }^{26}$ relating to Mieke Bal's narratological categories, ${ }^{27}$ implies that the persuasive devices in securitizing moves are located on the level of the text (or, here, the film) itself, and can be reconstructed without taking into account the audience's response empirically. The last two examples thus locate the effectiveness of securitizing moves theoretically in audience and context, yet refrain from making empirical audience responses the starting point of the analysis.

Thus, the 'audience disputes' have not led to a clear valorization of audience as a methodologically unavoidable instance in the analysis of securitizations. Rather, securitization studies have found ways to circumvent such methodological rigor while, on a theoretical level, accounting for the saliency of the category of audience. Thereby it has been mainly theoretical registers stemming from the humanities, such as intertextuality or rhetorical analysis, which, through arguing for the empirical implication of audience in securitizing moves, avoid the figure of self-referentiality as found in the CS and in poststructuralism together with the necessity to turn to an analysis of empirical audience responses. This rather unexpected, if not ironical, preliminary outcome of the 'audience disputes' raises the question of whether it was really the juxtaposition between "sociological" and "philosophical" theories of securitization (in Balzacq's terms) ${ }^{28}$ that formed the basis for the quarrel. In the next subsection, I will try to read the 'audience disputes' from another perspective, namely with a view to how the relationship between the authorization, or legitimation, of securitizations and their effectiveness was negotiated in these disputes.

\subsection{Securitization: Authorization/legitimation and effectiveness}

The three schools of securitization, sharing a constitutive-theoretical interest in how security issues are socially, politically and culturally produced,

26 Senn 2016.

27 Bal 2009.

28 Cf. Balzacq 2011. 
differ in the ways that they interrelate two aspects of securitization: the authorization, or legitimation, aspect on the one hand, and the aspect of effectiveness on the other hand. As the glimpse into the debates around the role of 'audiences' in securitizing speech-acts has revealed, the dispute, although represented by Balzacq as one between 'philosophical' and 'sociological' approaches to securitization, ${ }^{29}$ in actuality revolved around the separability of the two aspects. The CS, in particular as reconstructed by Vuori, ${ }^{30}$ merges authorization and effectiveness of a securitizing speechact. If the 'securitizing move' is conceptualized in analogy to performative speech-acts such as wedding couples or naming ships, ${ }^{31}$ then the securitizing actor's 'move' can be considered effective, assuming that he or she is authorized to perform that particular speech-act. The presence of a concrete audience is superfluous for this effectiveness to materialize, because the speech-act itself indicates the presence of a political legitimation of an actor to securitize policy issues. ${ }^{32} \mathrm{~A}$ securitizing move will thus be regarded as effective if its 'felicity conditions' (in Austin's sense) are met, that is, if the 'grammar of security' is conjured up by an authorized person. By way of contrast, Balzacq differentiates between the authorization and the effectiveness of securitizing practices. While the CS implies that securitizing actors must have some kind of authorization or legitimation in advance in order to reach out to a "target group" in the first place, ${ }^{33}$ this does not guarantee the effectiveness of their communication, in particular not with respect to audiences like parliaments or security councils on whose "formal support" (ibid.) securitizing actors depend, and which may express divergent views or outright reject the securitizing move. ${ }^{34}$

29 Balzacq 2005.

30 Vuori 2011.

31 Buzan et al. 1998.

32 Langenohl 2017.

33 Balzacq 2005, p. 185.

34 Cf. Williams 2003. - The general audience, or the public, is however regarded by Balzacq (2005, p. 190) as uninformed, passive, and dependent upon strategic actors. Lene Hansen (2012: 532) also sees the audience as "a dynamic space where actors seek to justify their policies and destabilise those of their opponents", thus refuting a notion of audience as 'public' in Habermas's sense, that is, equipped with the potential to intervene into securitization. This weakens the conceptual argument that securitizing moves should be seen as perlocutionary, as opposed to illocutionary, statements. 
These observations invite to pose the more general question of how authorization/legitimation and effectiveness of securitizing practices are more broadly interrelated in the field of securitization theory. This question is undoubtedly key for the aims of the present article, as authorization/legitimation and effectiveness are both key components of understandings of political power, especially so as Balzacq's critique points to the conceptual non-coincidence of those two components. The following table, relating important contributions to the debate, fans out a spectrum of conceptualizations of the nexus of authorization/legitimation and effectiveness (see Figure 1).

\begin{tabular}{|l|l|l|}
\hline Contributions & $\begin{array}{l}\text { Nexus of authorization/legitimation and effectiveness of } \\
\text { securitization }\end{array}$ & $\begin{array}{l}\text { Theoretical } \\
\text { label }\end{array}$ \\
\hline $\begin{array}{l}\text { Booth 1991, } \\
2007\end{array}$ & $\begin{array}{l}\text { Both authorization/legitimation and effectiveness have to be } \\
\text { critically investigated regarding their detrimental effects on } \\
\text { emancipation }\end{array}$ & $\begin{array}{l}\text { Normative } \\
\text { model }\end{array}$ \\
\hline $\begin{array}{l}\text { Wæver 1995; } \\
\text { Buzan et al. } \\
1998 ; \text { Vuori } \\
2011\end{array}$ & $\begin{array}{l}\text { Authorization/legitimation and effectiveness merge in the } \\
\text { performative nature of the securitizing move }\end{array}$ & $\begin{array}{l}\text { Speech-act } \\
\text { model }\end{array}$ \\
\hline $\begin{array}{l}\text { Huysmans } \\
\text { 1998; Hansen } \\
2011\end{array}$ & $\begin{array}{l}\text { Authorization/legitimation and effectiveness are recursively } \\
\text { connected through the self-referentiality of security dis- } \\
\text { course }\end{array}$ & $\begin{array}{l}\text { Discourse } \\
\text { model }\end{array}$ \\
\hline $\begin{array}{l}\text { Balzacq 2005, } \\
\text { 2011; Stritzel } \\
2012\end{array}$ & $\begin{array}{l}\text { Authorization/legitimation and effectiveness are conceptual- } \\
\text { ly independent: securitizing actors must have some authori- } \\
\text { ty/legitimation, but the success of their moves is contingent } \\
\text { on the broader context, especially the audience }\end{array}$ & $\begin{array}{l}\text { Audience } \\
\text { model }\end{array}$ \\
\hline $\begin{array}{l}\text { Bigo 2006; } \\
\text { Salter 2008; } \\
\text { Leander 2010 }\end{array}$ & $\begin{array}{l}\text { Authorization/legitimation emerge from attributions of pro- } \\
\text { fessional status in professional fields, while effectiveness re- } \\
\text { gards less speech acts than routine practices }\end{array}$ & Field model \\
\hline $\begin{array}{l}\text { Buzan/Wæver } \\
2009 ; \text { Balzacq } \\
\text { et al. 2016; } \\
\text { Buzan 2016 }\end{array}$ & $\begin{array}{l}\text { Both authorization/legitimation and effectiveness emerge } \\
\text { from constellations formed by different referent objects, dif- } \\
\text { ferent actors and different audience structures of securitiza- } \\
\text { tion }\end{array}$ & Fused model \\
\hline
\end{tabular}

\section{Figure 1: Conceptualizations of the nexus of authorization/legitimation and effectiveness}

As this brief, and most likely incomplete, sketch of different conceptualizations of the nexus between authorization/legitimation and effectiveness of securitization implies, securitization studies is strongly imbricated with the understanding that securitization and power are closely interrelated. Thereby, recent contributions tend to propose what I call a 'fused model' 
of the nexus of authorization/legitimation and effectiveness, which prioritizes the reconstruction of the complex constellations of securitization, with referent objects, actors and audiences forming integral parts of securitization. This model seems to emerge as new mainstream in securitization studies, all remaining differences between the different approaches notwithstanding. Thus it is all the more surprising that so far there is no systematic treatment of the question of exactly how this interrelation between securitization and power ought to be conceptualized. Instead, we find notions of power figuring at very different conceptual points within the respective models and the debates unfolding between them.

First, securitization studies claims for itself a critical stance toward realist understandings of power in the interstate system. Most drastically, this is articulated by Booth, ${ }^{35}$ who proposes to build security studies anew on a notion of emancipation of the individual as opposed to power politics attributed to the state. Yet, it also has repercussions in very recent contributions, such as in Buzan, ${ }^{36}$ who attributes to realism in IR an unreflected "state-centric, power-political understanding containing an assumption of conflict as a permanent condition of world politics". This points to a foundational scene of securitization studies insofar as they seem to depend in their coherence on a permanent delimitation from realist IR, including a tendency to relegate the notion of power to a traditionalist understanding of politics within an anarchic international system. This makes it comparatively difficult to conceptualize power in alternative ways.

Second, a constitutive-theoretical notion of power strongly leaning toward Foucault is entertained by poststructuralist contributions such as those by Huysmans. ${ }^{37}$ Here, power conceptually figures as a structuring force that creates scenarios within which securitization reigns unquestioned, so that securitization "does not refer to an external, objective reality but establishes a security situation by itself". ${ }^{38}$ This Foucauldian conceptualization of securitization power, unsurprisingly, shares with Foucault's notion of power the dilemma that either it has no room for resistance against securitization or, on the contrary, it sees the potential to resistance rather indiscriminately everywhere. ${ }^{39}$

35 Booth 1991, 2007, pp. 95-148.

36 Buzan 2016, p. 128.

37 Huysmans 1998, cf. also Bröckling 2012.

38 Huysmans 1998, p. 232.

39 Cf. id, pp. 245-248. 
Third, Thierry Balzacq has worked to form a complex understanding of power in securitization practices which, however, sticks to a resource-theoretical approach. He proceeds from a Bourdieuian analysis that conceptualized the seat of power in relations among actors informed by different kinds and amounts of "political or symbolic capital". ${ }^{40}$ Also, the relation between securitizing actors and audiences is revealed as being a power relation characterized by mutuality: "The 'power to' secure the compliance of the audience helps the securitizing actor 'fuse his/her horizon' with the audience's which, in turn, has the 'power to' acknowledge or ratify the claims put forward by the speaker". ${ }^{41}$ The inverted commas in Balzacq's argument seem to testify to a certain unease with a pure resource-theoretical understanding of power in securitization; accordingly, Balzacq indicates, through the notions of 'context' and 'dispositif', the position that both the legitimation and the effectiveness of securitization depend upon conditions that escape a resource-theoretical reconstruction. However, this distinction between securitizing practices and their frame conditions enables Balzacq to stick to a resource-theoretical notion of power all the same or, rather, to relegate the concept of power to instrumental action among securitizing actors and between them and their audiences.

This section has demonstrated that securitization studies, as it wishes to challenge the dominant realist paradigm in IR, strongly implies understandings of power in securitization acts and practices. It engages the question of how exactly two key components of understandings of power - namely that of authorization, or legitimation, and that of effectiveness ought to be conceptually interrelated. The disputes around the significance of 'audience' for the securitizing move to succeed are emblematic of these debates. Yet, so far there is little rigorous conceptualization of the notion of power in securitization studies.

This, as former as well as current contributions demonstrate, might have to do with the unease that securitization studies experience with respect to a classically realist understanding of inter-state power politics, from which they consistently tried to delineate themselves. Therefore, a closer look at the ways in which the realist IR background still informs, maybe even haunts, securitization studies might be a promising entry point into the attempt to reconstruct a notion of power from the different under-

40 Balzacq 2011, p. 26; cf. also Balzacq 2005, pp. 187-191.

41 Balzacq 2011, p. 26. 
standings of the political that securitization studies maintain, which will be accomplished in the next section.

\section{Conceptions of the political in securitization studies: The legacies of realist $I R$}

This section confronts the ambition of current securitization studies to critically intervene into (neo-)realist IR with the argument that much of securitization theory is still to a great degree informed by a realist IR legacy. First, this pertains to the interest mainly in inter-state or inter-polity relations shared by protagonists of the Copenhagen School and 'poststructuralist' contributions like that by Jef Huysmans. Second, the realist legacy of IR can be depicted in more recent contributions that shift securitization theory onto the terrain of a sociological field theory (Balzacq and Bigo, for instance), while retaining a notion of agency that is strongly informed by utilitarianism and strategic action. This sustained link to fundamental categories and paradigms of IR, while pointing to the often overlooked difficulties to apply securitization theory outside of IR, ${ }^{42}$ also harbors insights concerning the ways that notions of power in securitization studies are coupled with understandings of the political. As will be argued, the main bifurcation characterizing the field of securitization studies is that between a resource-theoretical notion of the power to securitize (the question of who 'has' power, and under what conditions) on the one hand, and a more complex understanding of power as relating to the ability of actors to cooperatively control the securitization dynamics in which they are imbricated on the other. Here, it will be argued that it is mainly the Copenhagen School that offers a way out of utilitarian and resource-theoretical notions of power in that it conceptually prioritizes not securitization but rather desecuritization in the sense of a valorization of cooperative political agency.

42 Cf. Bigo 2014. 


\subsection{The preoccupation with relations between polities}

Securitization studies formed in a historical context that was characterized by the falling apart of a supranational, bipolar order that organized most states in the northern hemisphere into two blocs, and many states in the southern hemisphere too, which often served as sites for proxy wars. The demise of this particular case of a 'macro-securitization constellation,' as it was later called by Buzan and Wæver, ${ }^{43}$ was responded to in IR by an interest in newly emerging structures organizing international conflicts, the most famous probably being the 'clash of civilizations' theorem of Samuel Huntington. ${ }^{44}$ Yet, although securitization studies kept returning to the question of supranational cleavages and more generally structures of cooperation and conflict, the CS stuck to a classical IR perspective insofar as they were interested mainly in relations among polities, or between polities and those collectivities that claimed politicity (for instance, regions claiming political autonomy) for themselves. ${ }^{45}$ Ole Wæver's work provides insight in how securitization studies did not leave behind the IR interest in the relations between more or less clearly demarcated polities or groups seeking political self-constitution, although they transferred it into a constructivist argumentation. For instance, Wæver explicated that the securitizing move implies a definition of the collectivity and a valorization of its political boundaries and spatial cohesion. This way, 'societal' securitization does not relate to security issues penetrating all fields of society, like in surveillance studies or governmentality studies, but rather refers to the invocation of the political collective and its 'identity' as the reference object of securitization. ${ }^{46}$

Moreover, those social fields which lack an entity that can be related to the survival interests of the polity, like the economy, do not qualify for genuine securitization, although economic issues may by transposed onto 'political' or 'societal' terrain, that is, made a subcase of the securitization of the state or its constitutive collectivity. ${ }^{47}$ Third, the adoption of the CS

43 Buzan and Wæver 2009.

44 Huntington 1994.

45 Cf. Hansen/Nissenbaum 2009.

46 Wæver 1996, pp. 109, 123. See for a re-actualization of this conception Abulof's (2014) study on 'deep securitization' in Israel.

47 Wæver 1996. 
approach by discourse-theoretical contributions (as in Huysmans) ${ }^{48}$ maintained, and even dramatized, the constitution of polities in modernity (that is, states) through relations to other polities, like in the argument that the ultimate discursive anchoring point of the 'grammar of security' is a double 'fear' characterizing modernity, namely fear of the other and fear of uncertainty. Through the invocation of a threatening other, which helps banning the specter of uncertainty, polities gain self-affirmation: "Security policies open a space within which a political community can represent and affirm itself. The policies thus create the condition of possibility for the political community". ${ }^{49}$ Thus, although Huysmans developed his argument concerning the transformation of uncertainty into an 'other' that must (and can) be made subject to security politics on the example of migrants and not of other states, ${ }^{50}$ he kept returning to the question of how such securitizations impact on international relations, thus retaining securitization studies' overall orientation toward the paradigmatic question of IR. ${ }^{51}$

Finally, in more recent contributions, CS scholars have endeavored to frame international relations within a context of other types of inter-polity relations more thoroughly than before. While Wæver's article on securitization dynamics in the European Union should be read as a stocktaking of how the supranational EU framework catalyzed and rearticulated tensions among polities in Europe, between them and groups seeking political selfconstitution, and between states and Brussels that made no strong claim to conceptual rigor, ${ }^{52}$ newer works conceptually highlight the ways that interstate relations are embedded within both geographically grander and thematically more heterogeneous relations. Regarding supra-IR securitization, in their article on 'macro-securitizations', Buzan and Wæver argue that between the inter-state level and the global, or world-system, level, there exists an intermediary level of securitization which consists of 'constellations' of other securitizations. ${ }^{53}$ The possible effect is that state securitizations may be clustered and condensed into supra-state securitization constellations, one of the most prominent examples being the Cold War:

48 Huysmans 1998.

49 Id., p. 238.

50 Id., pp. 238-244.

51 Cf. Huysmans 2006.

52 Wæver 1996.

53 Buzan/Wæver 2009. 
"[t]he key difference [from other securitizations] is that they are on a larger scale than the mainstream collectivities at the middle level (states, nations) and seek to package together securitisations from that level into a 'higher' and larger order". ${ }^{54}$ With respect to the thematic spectrum of possible securitization, Buzan highlights the contingency of borders and possibly conflicting securitization rationalities that result from the multiplication of possible referent objects of securitization that do not always sit easily with a polity's survival rationalities like, for instance, human rights issues or, more generally, human security. ${ }^{55}$ Yet, even here, the predominant analytical focus remains on the effects that this plurality of securitizations has for international relations and for the constitution of territorial borders and political collectivities.

The focus on inter-polity relations is mainly characteristic of the CS, not so much of the PS, which was from the outset strongly oriented toward a 'sociological' understanding of securitization, and was thus informed by theoretical resources that did not take international relations as their point of departure (for instance, Pierre Bourdieu or Michel Foucault). ${ }^{56}$ However, as will become clear in the next subsection, the PS featured and prolonged another characteristic of realist IR, namely a focus on strategic agency.

\subsection{The preoccupation with strategic agency}

While, as demonstrated in the last subsection, the CS represents the main locale for securitization theory's continuation of IR's interest in inter-polity relations, the PS presents itself as a stronghold of IR's emphasis on strategic agency as the common denominator of international relations. This emphasis on instrumental action is based on genuinely sociological contributions that have no direct connection to IR, such as the works of Pierre Bourdieu or Michel Foucault. For instance, Thierry Balzacq's self-proclaimed 'sociological' theory of securitization emphasizes the strategic re-

54 Id., p. 257.

55 Buzan 2016. On human security cf. Daase 2011, 2012.

56 Although the CS fashions a notion of 'social structure' too, it mainly denotes the effect of core components of a given societal order, or hierarchy, on the ways that polities interrelate with each other, thus referring to an 'international social structure' (see Buzan 2016, pp. 132-134). 
lationship that securitizing actors maintain toward their audience. With a particular view to their relation to a mass-mediatized public, securitizing actors appear as strategic actors whose pledges for public support are based on a power differential between them and that audience, thus rendering the audience more or less passive. ${ }^{57}$ At the same time, and referring to the works by Didier Bigo ${ }^{58}$ and Pierre Bourdieu, ${ }^{59}$ Balzacq promotes a capital-theoretical approach that localizes the action resources of securitizing actors in a 'habitus' composed of different sorts of 'capital' that endow these actors with the capacity to maneuver and pursue their strategies within differentiated 'fields' of security. ${ }^{60}$ This strategic, or instrumentalist, approach to securitizing agency is ameliorated by considerations of 'context,' which forms the frame for strategic action. In some sense, Balzacq's suggestion reminds of neoclassical economic models of utilitarian action in which (securitizing) actors pursue utility maximization under 'constraints' (rendered as 'context' by Balzacq), ${ }^{61}$ were it not that the 'context' is viewed by Balzacq as an enabling, as opposed to restraining, condition for securitizing moves. What, however, is common to Balzacq's suggestions, neoclassical agency models, and realist IR is the axiomatic role of strategic and instrumental action. This orientation is also clearly present in more recent contributions that take into account the discursive substrate of the context of securitization as, for instance, in Stritzel's call to consider not only the power of discourse, but also the power of strategic actors in discourse. ${ }^{62}$

It is interesting to compare the emphasis on strategic action in the PS with the ways that strategic action figures in the CS. Here, the picture is somewhat more differentiated. On the one hand, the 'securitizing move', which stands at the conceptual center of the CS notion of securitization, has been perceived as alluding to a decisionist understanding of politics

57 Balzacq 2005, p. 190.

58 Bigo 2000; cf. Bigo 2006.

59 Bourdieu 1990.

60 Balzacq 2011, p. 26.

61 Cf. Kirchgässner 2008.

62 Stritzel 2012, pp. 550-552. This focus on strategic action was challenged from a variety of approaches, like poststructuralism (for instance, Huysmans 1998), but also feminist interventions (to which Booth, representative of the Welsh school, referred already in 1991), postcolonial and Marxist theory, that all shared an interest rather in the structural conditions of inequality entrenched in the international system than in the agency of securitizing actors (Buzan 2016, p. 128-129). 
borrowed from Carl Schmitt, ${ }^{63}$ where politics ultimately boils down to the act of announcing the state of exception as the fundamental move through which political sovereignty is constituted. Rens van Munster, for instance, claims that Schmitt and the CS share a conceptualization of securitization that is in the last instance derived from the scene of war: "[f]or them [CS], too, the exceptional logic of securitisation is captured most adequately by the logic of war". ${ }^{64}$ According to this interpretation, the 'securitizing move' appears as the ultimate strategic and instrumental act. However, Michael C. Williams has pointed out that, although there is a clear conceptual affinity between the gesture of the securitizing move and that of declaring the state of exception, ${ }^{65}$ the CS conception necessarily drifts over into the conceptual register of communicative action sensu Habermas: 66

"As speech-acts, securitizations are in principle forced to enter the realm of discursive legitimation. Speech-act theory entails the possibility of argument, of dialogue, and thereby holds out the potential for the transformation of security perceptions both within and between states. [...] It is via this commitment to communicative action and discursive ethics, I would like to suggest, that the Copenhagen School seeks to avoid the radical realpolitik that might otherwise seem necessarily to follow from the Schmittian elements of the theory of securitization. [...] This element of the Copenhagen School is clearly illustrated in the concepts of 'desecuritization' and 'asecurity' which form integral aspects of securitization theory." 67

This argument, yet, eclipses the strictness of the Austinian speech-act-theoretical architecture of the CS, about which it has been argued that the audience response, to which Williams refers, has no empirical but a conceptual significance for the CS (see above), so that the theoretical point about the securitizing move is precisely its ability to bracket empirical audiences, and thus also "the possibility of argument, of dialogue" ${ }^{68}$ In other words, while Williams argues that securitizing moves, like any speech act, are in principle open to response and deliberation, the key argument in the CS is that the 'performativity' of the speech act and its legitimacy are ultimately grounded in a 'grammar of security' which, as it were, outmaneu-

63 Schmitt 1934.

64 Munster 2005, p. 5.

65 Williams 2003, pp. 515-521.

66 Cf. Habermas 1987.

67 Id., p. 523; cf. also Hansen 2012, pp. 529-531.

68 Williams 2003, p. 523. 
vers any attempt to question the securitizing speech act from the very start. However, Williams also points to the fact that, in order to understand the ways that the CS views securitizing speech acts, one has to take into account not only the notion of securitization but also that of desecuritization. In the next subsection, I will argue that, if viewed from the perspective of desecuritization, the tense relationship between an Austinian and a Habermasian notion of speech act can be resolved, and at the same time a view can be gained on the deep structures of the notion of the political that the CS entertains.

\subsection{Notions of the political}

In this subsection, I will trace the argument that the CS in fact refutes an understanding of securitization as stemming from strategic and instrumental action. My point of departure is Stefano Guzzini's interpretation of the CS and especially of Wæver's works. ${ }^{69}$ According to his interpretation, the core concept of the CS is not securitization, but desecuritization. Against the historical background of successful diplomatic efforts to shift political deadlocks between the superpowers back onto diplomatic terrain (notably the ostpolitik of Willy Brandt and Egon Bahr), Guzzini argues that Wæver's interest lay first and foremost with those processes that conquered the security dilemmas of the Cold War. ${ }^{70}$ Within the grips of such security dilemmas, 'strategic action' appears as a mere mirage, as they coerced political actors into executing a logic of securitization that, as long as the 'strategic' view held, paradoxically left them without any control over the situation. Put differently, under conditions of security dilemmas, strategic action can never be autonomous. According to Guzzini's reconstruction of Wæver's approach, autonomous and cooperative agency can only be regained if actors agree to reengage in a communicative relationship that, among other things, is also open to the reformulation of 'strate-

69 Guzzini's 2015.

70 See also Hansen 2012, pp. 537-538. 
gic' interests. ${ }^{71}$ As securitization is opposed to diplomacy, ${ }^{72}$ strategic agency is opposed to autonomous agency which can only succeed in an interrelation with other actors. Such desecuritizing agency has a power dimension, too, diminishing the opposing party's chances to securitize in their turn as securitization as a legitimate means of power becomes discredited. ${ }^{73}$

Seen from this angle, the notion of the political entertained by the CS shuttles between a Schmittian ${ }^{74}$ and an Arendtian ${ }^{75}$ - not, as Williams has it, a Habermasian - understanding of the political, that is, between one which sees the core of the political in the exceptional act that constitutes sovereignty, and one that views the political as an arena of cooperation even among adversaries. ${ }^{76}$ According to Guzzini's reading, the difference between these two understandings has been for the CS ultimately a normative question, with Wæver being interested predominantly in the ways securitization can be turned around into desecuritization, with mutually responsive agency ensuing. ${ }^{77}$ In other words, empirical (de-)securitizations - this is how I understand Guzzini's argument - necessitated a conceptual notion of (de-)securitization, which was normatively split into the affirmation of desecuritization and the criticism of securitization. Thereby, the notion of desecuritization may not only be read as following and correcting securitizing moves, but also, and more fundamentally, as highlighting the

71 Lene Hansen (2012, pp. 534-535) has argued that Wæver insists on the political responsibility that both securitization and desecuritization have to confront each other, as, according to the CS, neither move can consistently claim any objective state of affairs in order to legitimize (de)securitization. This interpretation invokes Wæver's critique of poststructuralist positions which, according to him, tend to ignore the question of actors' responsibility for securitization and desecuritization alike. However, here I would point out that, even if that responsibility is present from the standpoint of a normative understanding of (de-)securitization, it is still worthwhile to embrace Guzzini's argument that the possibility of a redemption of responsibility is more aligned with desecuritization because securitization structurally diminishes the opportunities for responsible agency.

72 See also Huysmans 2006.

73 Guzzini (2015) cites the example of the demise of state socialism when power holders, for instance in the GDR, lost their legitimation to securitize the confrontation with the west.

74 Cf. Schmitt 1934.

75 Cf. Arendt 2006.

76 Therefore, desecuritization does not necessarily announce the resolution of a conflict but only its 'tending' (Dubiel 1999; cf. Hansen 2012, pp. 536-538).

77 See Wæver 2000. 
constituted nature of 'politics as usual', just as securitization is conceptualized as constituting a departure from 'politics as usual.' Therefore, although 'desecuritization' seems to indicate a sequentially later stage than securitization, in conceptual terms it equals securitization in bringing about a certain state of the political - namely, the grounding of politics in the political, which in turn is seen in the possibility to engage in cooperative action even with adversaries. ${ }^{78}$ Thereby, it is through the normative argument that desecuritization rescues the political as field of cooperative agency that desecuritization is rendered as conceptually prior to securitization, even as securitization always empirically challenges the logics of desecuritization.

Compared to this very complex notion of the political as found in the $\mathrm{CS}$, the Welsh and the Paris schools are more clear-cut in their premises. According to the Welsh School, emancipation and security are identical both theoretically and empirically. ${ }^{79}$ The political thus appears as an allencompassing sphere of human interactions where actors discover their interdependencies. In this, there is a certain affinity to the notion of the political as heralded by desecuritization in the CS; however, the challenges that securitization puts to that notion of the political are less clearly explicated, but rather rejected in a wholesale way. In turn, the PS has no theoretically refined notion of the political, but insists that the political is imbricated with the societal or the social. The focus on practices of securitization, in clear demarcation from the CS, is meant to drive home the point that securitization is characterized less by political speech acts or discourses but rather by practices that operate below the radar of politics.

With respect to the interrelated questions of how securitization studies refer to IR and how this reference figures in the notion of the political entertained by the three schools, the Welsh School and the Paris School seem to herald a radical questioning of IR. The Welsh School identifies the political with multilateral cooperation for the sake of the wellbeing of individuals and societies, not states, whereas the PS, focusing on practices of securitization, subverts any notion that official politics as such - for instance, international relations - is of much significance for understanding the logic of securitization. In contrast to such clarity, the CS appears to be

78 Bonacker and Bernhardt (2003, p. 228) thus rightly point out that for the CS the condition of peace (understood in terms of a 'security community' in the sense of Karl Deutsch (1970) is first of all conditioned by the absence of securitization.

79 Booth 1991, 2007; Wyn Jones 2005. 
more ambivalent, shuttling between a Schmittian and an Arendtian notion of the political, affirming the latter while at the same time seeing it exposed by the logic of the former. However, this is not the whole picture. In the next subsection, which eventually turns to the question of how power is conceptualized in the three schools respectively, I will argue that the CS's normative opting for a notion of the political as aligned with desecuritization, not securitization, is the major feature by dint of which the CS, among all schools of securitization studies, performs the most radical questioning of IR perspectives in the study of securitization, and can thus be regarded as the most fruitful perspective to conceptualize the power dynamics of securitization in a more general framework.

\subsection{Conceptions of power}

The PS, as has already been pointed out, maintains a 'sociological' understanding of securitization. Accordingly, its notion of power is derived from sociological theory, in particular Pierre Bourdieu's theory of social fields, although references to Foucault's notion of dispositif add a certain dose of discourse theory. Still, the focus on instrumental action, made possible by the distribution of different forms of capital among securitizing actors, implies a strong resource-theoretical notion of power: power is had by securitizing elites due to their ability to accumulate social, cultural and symbolic capital within the context of restricting and enabling structures termed 'context' or 'dispositifs'. The WS, at first glance, holds a diametrically different notion of power, rejecting the very concept of power as the source of oppression in the name of security. 'Power' as a concept has to be eliminated from security thinking, giving way to 'emancipation'. The project is thus, as it was often before in moral philosophy to which Booth adheres, ${ }^{80}$ to deconstruct the seemingly self-evident centrality of power in the understanding of inter-human relations. Yet ironically, the very refutation of power as a legitimate concept in security thinking reproduces its architecture as a notion strongly featuring a resource-theoretically backed utilitarianism which aligns closely with the notion of power in the PS, even if that concept is viewed in a less moralizing way by the latter. Against this background, the question is whether the CS might hold more 
nuanced understandings of the power in securitization that might help to lead the debate out of the realms of IR proper. ${ }^{81}$

Vuori argues that the CS's argumentative kernel is illocution, not perlocution, ${ }^{82}$ the consequence being that interests and purposes of securitizing actors, and indeed the empirical effects of securitization, have to be eliminated from the conceptual picture in order to fully grasp the radically semantic constitution of securitization. While Balzacq, ${ }^{83}$ as outlined above, has reproached the CS of reducing the performativity of securitizing moves to illocution at the expense of perlocution, a deeper rationality of this conceptual architecture might be found in an, perhaps implicit, attempt by the CS to fully abandon a power model of strategic actors who wish to effect particular states of affairs. Seen from this angle, the CS not only theoretically deconstructs 'security' as relating to objectively existing conditions of threat, but also, methodologically, any understanding that securitization has anything to do with strategic agency. According to this (implicit) argument, securitizing actors conduct securitizing procedures in the sense of 'naming a ship', as Buzan et al. explain in line with the notion of illocution, ${ }^{84}$ that is, they follow role scripts derived from the 'grammar of security' and located beyond the instrumental reach of actors. From this perspective, it would be hard to tell from particular empirical speech acts whether they are performed as 'strategic action' or as a slavish execution of the 'grammar of security', because this distinction would be preordained on the methodological level. To put it more drastically, from the perspective of the securitizing move as an illocutionary speech act, it is impossible to distinguish securitizing actors from securitization muppets, who declare what their experts (or whoever else) told them to declare.

In light of these considerations, I propose to depict the radicalism with which the CS articulates a rejection of core assumptions of IR not in their turning away from questions of how polities relate to each other (in fact, they are much more interested in that question than the WS or the PS), but in their insistence that strategic action is not at the core of securitization. On the contrary, securitization operates according to a logic which leaves absolutely no room for strategic action but instead performs a speech act that is adamantly determined by a role script generated by the 'grammar of

81 Cf. Bigo 2014.

82 Vuori 2011, pp. 154-155.

83 Balzacq 2005.

84 Buzan et al. 1998. 
security'. The 'securitizing move' is the mere execution of that role script, and the securitizing actor is the empirical incarnation of a homo sociologicus in Ralf Dahrendorf's sense, ${ }^{85}$ that is, of a sociological actor model that views action solely as the blind execution of others' expectations. The securitizing actor is, to put it even more bluntly, a slave to securitization. This is a most radical deconstruction of any claim that power resides with the securitizing move if understood as strategic action, and thus a most effective refutation of utilitarianism as the core component of 'realist' IR. Instead, power can only materialize as a consequence of desecuritization in Wæver's sense, ${ }^{86}$ that is, under conditions in which the factual interdependency between actors (for instance, but not confined to, state actors) is made subject to coordinated action.

\section{The power to securitize and the power of securitization: Towards a relational model of power in securitization}

In the last section, it was argued that the CS, in comparison with the PS and the WS, gains a much greater distance from the IR legacy in securitization studies because it casts radical doubt on any understanding that the securitizing move is grounded in the sovereign execution of power based on power resources. This can be linked to Stefano Guzzini's conviction that the historical background for the emergence of the CS was an interest in processes that led to the dismemberment of constellations of securitization. ${ }^{87}$ In such constellations, all involved actors - like the governments of the Soviet Union and of the NATO states - found themselves locked up in a spiral of mutual securitizations that left ever less space for mutually coordinated action in international relations. Agency, in the sense of coordinated action, thus, lies not in securitizing, but in desecuritizing moves, as it is only the latter that can re-establish coordination beyond the execution of the 'grammar of security'. It is the aim of this section to generalize this historically circumscribed scenario, according to which only desecuritization can be associated with agency as opposed to conduct in conformity, into a more encompassing, and conceptually deeper grounded, model. The normative outlook of the CS - namely, according to my interpretation that

85 Dahrendorf 1965.

86 Wæver 1995.

87 Guzzini 2015. 
power is not in the securitizing move because it is not instrumental action but role-conforming action, and that it resides instead in desecuritization, that is, the capability to cooperatively steer interdependencies apart from role scripts - must be transferred into an analytical model.

A first starting point for such a theoretical generalization is the argument made above that, according to the CS, power, in an Arendtian sense, emanates from interdependencies. For Wæver, power is identical with the power to desecuritize because it is only in desecuritization that policy issues can be shifted back onto a terrain where mutual political coordination between opposing camps becomes possible. A second important vantage point is the argument that securitizing moves - for Wæver, rather expressing actors' powerlessness than power, in the sense that they are deprived of the capacity to coordinated political agency even with adversaries may have consequences that cannot be fully controlled by securitizing actors because their capability to engage in mutual action coordination is severely limited by securitization. In other words, securitization may exert a power over securitizing actors - and, as in the case of a political confrontation like the Cold War, virtually everyone else.

This way, the power of securitization can be conceptually delineated from the power to desecuritize. This presents us with a first rough relational power model that distinguishes between the agency in desecuritization and the effects of securitization. However, contrary to the normative grounding of these two modes of the operation of power in (de)securitization as is characteristic of the CS, for the present purposes it is unnecessary to exclusively align securitization with the power of effects and desecuritization with the power of agency. For the major conceptual dividing line is not that between securitization and desecuritization, but that between coordinated agency (which may aim at both securitization and desecuritization) and uncontrollable, or unaccounted for, consequences (which may stem from both securitization and desecuritization). While the CS has given us ample ground for distinguishing the power dimension of securitization into the two modes of 'power of' and 'power to', it is now time to anchor this distinction in a conceptual ground that leaves the CS's normative framework behind, thus arriving at a more rigorously theorized, relational model of power in securitization and desecuritization. This will be done through introducing Norbert Elias's relational paradigm of power. 


\subsection{Norbert Elias's relational model of power}

According to Norbert Elias, the subject area of sociology is a stocktaking and a resulting typologization of "networks of interdependencies" (Interdependenzgeflechte) between actors. ${ }^{88}$ Together with Gabriel Tarde and Georg Simmel, ${ }^{89}$ he thus can count as a representative of an 'interactionist' (or maybe rather 'associationist') sociology. He has common ground with Tarde and Simmel also by dint of the equal analytical valuation of psychic-affective and social processes, as is evident from his famous theorem regarding the "process of civilization" in Europe since the Middle Ages. According to this theorem, the process of civilization refers to an increasing tendency to self-discipline through anticipation of possible interpretations of one's behavior by others. It was conditioned by a change of social figurations which affected first the noble elite and then trickled down into the bourgeoisie, thus disseminating through society. This figurational change was the result, most notably, of changing power structures in late-feudal society. While the 'high' Middle Ages where characterized by outspokenly decentralized power structures, which in the absence of an overarching authority had enabled feudal lords to unleash the force of their affects upon their subjects, the increasing centralization of political power - for instance, in the French royal court - resulted in the emergence of a social milieu of courtiers in which the rise and fall in the king's grace became strongly dependent on the attributions by other courtiers. Elias argues that this process, on the psychic level, effected routines of affect control, and on the intrapersonal level, the emergence of a social etiquette. ${ }^{90}$

For the purposes of this chapter, Elias's considerations are less important with a view to their historical statement, which has been met with criticism among historians (cf. Duindam 1998), but rather because they exemplify a conceptually relational model of power. In his later works, Elias often uses the notion of 'balance of power' (Machtbalance) ${ }^{91}$ in order to ground power in his relational reasoning. A balance of power is a more or less stabilized relationship structure between individuals belonging to different groups constituted by attribution. Within this relationship structure, members of the different involved groups have different possibilities to

88 Cf. Elias 1969, p. 172.

89 Cf. Tarde 1894 and Simmel 1989.

90 Elias 1976a, 1976b.

91 Elias 2005 (1989), 2006 (1986). 
engage in agency, both with respect to themselves and to members of the other groups. The differences between those options have, in their turn, different origins, for instance, varying institutionalized spaces of action of the presence or absence of social institutions not directly involved in the relationship structure and the stakes held by its groups, such as the state and its legal institutions. ${ }^{92}$ Elias thus proposes a figuration-theoretical conception of power, addressing the interdependencies and interrelations between actors in their membership roles and stakes against the background of more encompassing relationship networks. His conception of power is opposed to a resource-theoretical or domination-theoretical notion of power, as that which is 'possessed' by actors and 'effected' upon other actors and which hardly allows complex reconstructions regarding the relational, effectual and conditional processes and structures that put power to work. Instead, Elias's conception invites to widen the perspective beyond securitizing actors and securitized actors to wider societal, political and cultural networks of interdependencies which are directly involved in the emergence and the changing of balances of power, even if they might not directly intervene in the 'execution' of power.

It might be objected that Elias's conception of balances of power in figurations is not that dissimilar from the balance-of-power conception so characteristic for realist IR, thus effectively abandoning the CS's important challenge to realist IR, namely to deny that securitization equals strategic and instrumental action based on power resources. There are, however, important differences between the two conceptions of balances of power. First, Elias's conception does not presuppose any given entity or set of entities, such as states. This makes his model much more open-ended in comparison to realist IR, which regularly proceeds from the stipulation of an inter-state system as the precondition for its theorizing. In fact, Elias's model is capable of encompassing security-related actors from individuals, private companies, political movements, state institutions,

92 See Elias (1986) for an illustration of his notion of power balance, developed in an analysis of gender relations in the Roman Empire where he argues that the status of women in society was decidedly affected by legal innovations, carried out by the state, regarding their right to property and inheritance. Elias's theoretical argument thus exemplified is that power relations between members of different group membership resulting from social ascriptions (here, gender ascriptions) is crucially impacted by the structure of the overall figuration of which, on from a certain point in historical time, the state becomes a part. 
supranational institutions, all the way up to 'macro-securitizations'. ${ }^{93} \mathrm{Sec}-$ ond, Elias's model is particularly apt in conceptualizing the intervening effects of third parties on power balances unfolding between two parties, and thus to give very nuanced accounts of Balzacq's 'contexts' of securitization. ${ }^{94}$ Third, it is also, in principle, capable of accounting for the effects of non-human agency on processes and effects of securitization, such as 'actants' in the sense of Actant Network Theory, ${ }^{95}$ as it shares with other associationist approaches in sociology the conviction that the analysis of interrelations and interdependencies must have conceptual priority over any statement about the 'nature' of the entities between which interrelations and interdependencies unfold.

\subsection{An analytical matrix of power in securitization}

These elaborations on Elias's conception of power can now be used as a platform from which to embark upon a conceptualization of power in securitization. In particular, Elias's understanding of power as emerging in (shifting) balances within figurations between actors and/or actants lends itself to an understanding of power as unfolding structure of action options that may enable, but also restrict, actors' capabilities in securitization processes. The following matrix of power in securitization is meant to provide a conceptual architecture for understanding the particular role of power in securitization across the different 'schools' of securitization as well as across two different modes of power which pertain to the process of securitization and to its effects, respectively (see Figure 2).

The two power modes are derived from the above discussion of Wæver's refutation of the IR argument that securitization inevitably materializes instrumental power, analytically distinguishing between the power to securitize as that figuration which enables securitization, and the power of securitization as the (often unintended or unaccounted for) effects that gain momentum as the consequence of securitization. The advantage of this distinction is that it brings together considerations that regard both the constitution of securitization and its effects. The two aspect structures of securitization, in turn, take up the debate in securitization studies about the

93 Buzan/Wæver 2009.

94 Balzacq 2005, 2011.

95 Cf. Latour 1996, 2000. 


\begin{tabular}{|c|c|c|}
\hline $\begin{array}{c}\text { Aspect structure of } \\
\text { securitization }\end{array}$ & \multicolumn{2}{|c|}{ Mode of power in securitization } \\
\cline { 2 - 3 } & $\begin{array}{c}\text { Power to securitize } \\
\text { (mode I) }\end{array}$ & $\begin{array}{c}\text { Power of securitization } \\
\text { (mode II) }\end{array}$ \\
\hline $\begin{array}{c}\text { Representing security } \\
\text { (CS, WS) }\end{array}$ & Field 1 & Field 2 \\
\hline $\begin{array}{c}\text { Engineering security } \\
(P S)\end{array}$ & Field 3 & Field 4 \\
\hline
\end{tabular}

Figure 2: Analytical matrix of power in securitization

necessity to supplement a practice dimension of securitization to the speech act dimension proposed by the CS. In other words, it makes an analytical distinction between acts that aim at communicating, or representing, something as related to security ${ }^{96}$ and acts that aim at engineering security (in whatever particular sense) in a particular field of practice.

Field 1 in the matrix approaches the power to securitize in the sense of the CS and, partly, the WS. It refers to acts of communication that aim at representing security - that is, of framing a certain issue as pertaining to security. The power dimension of such acts can be seen in the figurations which enable them. For instance, according to the orthodox reading of the $\mathrm{CS},{ }^{97}$ a 'grammar of security' must be available that lends the 'securitizing move' illocutionary performativity. That this grammar cannot be taken for granted is exemplified by Huysmans, ${ }^{98}$ who argues that it is only in modernity that such grammar develops as states tend to derive the symbolic sources of their existence from a stipulation of other states as 'enemies'. In a similar vein, Booth's intervention points to at least the normative possibility that that grammar might be challenged on the grounds that security ought not to pertain to states but to people, thus delegitimating the grammar of security to a certain degree. ${ }^{99}$ Another possibility to understand the power dynamics in Field 1 is to take Balzacq's critique of the CS seriously, and thus to ask how relevant audiences can be persuaded and/or mobilized to support the securitizing speech act. In any case, the securitizing

96 This formulation heralds, in methodological terms, a more encompassing understanding than 'speech act' in the CS sense.

97 Cf. Vuori 2011.

98 Huysmans 1998.

99 Booth 1991, 2007. 
act of communication is empowered by social as well as discursive figurations which cannot be taken for granted but have to be historically reconstructed.

Field 2 addresses the question of the effects that securitizing acts of communication may have on securitizing actors and others concerned by the securitizing move. From a standpoint developed analogously to Elias's conception of power, these effects may restrain actors' options as an effect of securitization. For instance, as Wæver has argued, securitization during the Cold War tended to lock political actors into a political deadlock from which they found it very hard to escape without questioning their political mandate that enabled them to perform securitizing moves in the first place. ${ }^{100}$ Elias, who himself addressed the Cold War's arms race, argued that it forms an example of a figuration that unfolded at the expense of actors' intentions and their capability of cooperatively steering the conflict. ${ }^{101}$ Further, power effects of securitizing acts of communication regard the ways that individuals and groups find themselves exposed to the logic of an 'othering', ${ }^{102}$ which may strongly impact their agency options and capacities to resist the securitizing move.

Field 3 groups those practices that aim at installing or maintaining security in particular fields of practice, such as international relations, 'inner security', border controls, the fight against epidemics, etc. The power to securitize refers here to those social, technological and discursive figurations that enable securitizing action, for instance, through political authorization, technical equipping, or societal legitimization. These different figurative levels may have varying impacts on the power to securitize. For instance, Bigo has argued that, with respect to the policing of the EU borders, 'security experts' have attained an influential position due to their legitimization through various bodies of (partly academic) expertise, while their political (more precisely, democratic) legitimation remains as doubtful as it is unimportant for their position within the security figuration. ${ }^{103}$ Other researchers have made the point that in highly technicized security settings, such as imaging techniques in controls at airports, technology it-

100 Cf. Guzzini 2015.

101 Elias 1983.

102 See Huysmans 1998.

103 Bigo 2006. 
self has risen to a legitimacy status of self-evidence that is hardly questioned. 104

Finally, Field 4 pertains to the effects of such securitizing practices. These may be seen not only in the effects that securitization has on various social constituencies (like migrants to the EU from Africa or airline passengers), but also in the ways that these securitizing figurations create path dependencies that attain a self-immunizing status. ${ }^{105}$ Many studies within the framework of the Paris School, dealing with the emergence of security professionalism and related bodies of knowledge and practices of social authorization, might be interpreted as reconstructions of the power of securitization. In other words, while securitizing practices may more effectively 'secure' practice fields the more elaborated and institutionalized they are, their very institutionalization may effect blind spots through which alternative options to tackle a perceived crisis are effaced. ${ }^{106}$

\subsection{A typology of power in securitization}

Having introduced the four fields in the matrix of power in securitization, I now wish to advance to a more systematic analytical model, amounting to a typology of power in securitization (see Figure 3).

Field 1 addresses the power to securitize, in the sense of performing securitizing acts of communication. This power can be conceptualized as the creation of a public scene in which a decision between two antagonistic political options must be made - namely, to proceed with a given politics, or to transpose it into the register of the 'grammar of security'. This mode of power thus consists in the presence of a figuration that allows effecting a scene of radical political decision. The question is, thus, how such a figuration can be brought about. It is influenced by a variety of factors within the overall figuration, like the presence or absence of counter-securitizing actors, juridical restrictions on political communications (like in Germany,

104 Rauer 2012.

105 Barnard-Wills/Ashenden 2012.

106 This regards, for instance, the securitization of global public health by the UN, which, according to Weber-Mosdorf (2013, p. 163), suspends an interest in the determining factors of the spread of diseases. For similar processes in the engineering of security through private companies and the reformulation of national security in terms of 'national risk registers' see Frevel/Schulze 2012 and Hagmann/Dunn Cavelty 2012. 


\begin{tabular}{|c|c|c|}
\hline \multirow{2}{*}{$\begin{array}{l}\text { Aspect structure of } \\
\text { securitization }\end{array}$} & \multicolumn{2}{|c|}{ Mode of power in securitization } \\
\hline & $\begin{array}{l}\text { Power to securitize } \\
\text { (mode I) }\end{array}$ & $\begin{array}{c}\text { Power of securitization } \\
\text { (mode II) }\end{array}$ \\
\hline $\begin{array}{c}\text { Representing security } \\
\text { (CS,WS) }\end{array}$ & $\begin{array}{l}\text { creation of a scene of } \\
\text { decision (field 1) }\end{array}$ & $\begin{array}{l}\text { effects of the decision- } \\
\text { ist logic (field 2) }\end{array}$ \\
\hline $\begin{array}{l}\text { Engineering security } \\
\text { (PS) }\end{array}$ & $\begin{array}{l}\text { creation of a pattern of } \\
\text { identification (field } 3 \text { ) }\end{array}$ & $\begin{array}{l}\text { effects of the pattern of } \\
\text { identification (field 4) }\end{array}$ \\
\hline
\end{tabular}

\section{Figure 3: Typology of power in securitization}

the legal ban on volksverhetzung), or a shift in the relation between securitizing actors and their relevant audiences.

Field 2 addresses the consequences that arise from such acts of securitizing communication for the figuration, encompassing both those relational elements that helped bringing the scene of decision about as well as those relational elements impacted by the consequences of that scene. One way to conceive of these consequences is to render them in terms of Heinrich Popitz's typology of power, which will be returned to with respect to Field 4 (see below). According to Popitz, one major type of power is "authoritative power", which rests on a constant relationship between the dominant actor and the subjected actor, in particular "on a twofold process of recognition: on the recognition of the supremacy of others as those who set the criteria, as those who are crucial, and on the striving to be recognized by those crucial others and to receive signs of probation from them". ${ }^{107}$ The act of communicating securitization may unfold such power effects under the condition that the creation of a scene of decision in which securitization rests creates an opportunity for securitizing actors to establish themselves as "those who are crucial" and thus can allocate recognition.

"Authoritative power" may have more complicated consequences, though. With respect to the securitizing actors, their figuration may become more strictly differentiated with respect to actor roles. For instance, a political actor having performed a securitizing act of communication might find herself unable to 'call back' that act, as her position within the power balance would suffer from such a move, which might seem inconsequential to relevant audiences. Alternatively, other actors belonging to the securitizing figuration may profit from the securitizing move at the ex-

107 Popitz 1992, p. 29, author's translation. 
pense of the securitizing actor, claiming for themselves more radical and 'more securitizing' positions. With regard to those actors and groups against whom the securitizing act is directed, they may find themselves under political and public pressure to recognize the securitizing actors' supremacy; or they might, on the contrary, be empowered by the act in the sense that they receive from it a public platform to articulate their response. ${ }^{108}$

In a more general framework, securitizing acts of communication may unfold a power that Popitz terms "the power to establish data" (datensetzende Macht). ${ }^{109}$ 'Data' may be interpreted here as epistemic elements that, for instance, concern conventions of representation enshrined in the 'grammar of security'. The invocation of such grammar (if it is available and uncontested, see above) may result in discursive power effects. This dimension of effects of securitizing acts of communication can be aligned with studies operating under Foucault's notion of 'governmentality' 110 with respect to contemporary regimes of security. ${ }^{111}$ They demonstrate how 'dispositifs' of security ${ }^{112}$ pre-shape and restrain political and societal options to address security. Other works, for instance by Christopher Daase, ${ }^{113}$ may be interpreted as commentaries on the power effects of securitizing acts of communication inasmuch as they are interested in the (partly unintended) consequences of a widening of proclamations and ambitions of security beyond the reach of existing political institutions, most notably the state (as in 'human security'). In terms of the figuration-analytical register advocated here, securitizing acts of communication are established as a relevant semantic frame for ever-wider fields of society that is to say, they are legitimized. On the one hand, this leads to a restraining of types of relationships between groups of actors, ${ }^{114}$ while on the other hand, certain groups of actors are accredited with newly legitimate claims (for instance, NGOs) whose redemption cannot always be

108 Cf. Williams 2003.

109 Popitz 1992, pp. 23-27.

110 Cf. Foucault 2007.

111 Bröckling 2012.

112 See also Balzacq 2011.

113 Daase 2011, 2012.

114 Bröckling 2012. 
guaranteed within the existing figurational interdependencies (like, still mostly, states in inter-state relations). ${ }^{115}$

Field 3 concerns those figurations that empower actors/actants to 'create' security. The scare quotes around 'create' indicate that what is at stake here is not so much the question whether security is effectively created or not, but rather that certain practices and 'routines'"116 lock in that claim for themselves to tackle a security problem. This involves a widening of the view regarding actors of securitization as it is mostly not political elites but diverse organizations, including private service providers, that are accredited to identify threats and control them. ${ }^{117}$ This is evident, for instance, in studies devoted to the analysis of security procedures on airports, ${ }^{118}$ which argue that the agency of humans and non-humans have to be analyzed in their interdependencies in a symmetrical manner. ${ }^{119}$ This approach can easily be rendered in a figuration-theoretical register: Power balances of securitization encompass not only figurations of human beings in their different group memberships, but also interdependencies that involve non-human agency, like body scanners, automatized information technologies, and more generally infrastructures. ${ }^{120}$ The figuration-analytical question is thus: which are the factors that determine those power balances that stretch between securitizing (human and non-human) actants and those subjected to control? This regards not only material artifacts but also institutional questions, like that of the juridical frame conditions of data transfer or political positions on the accreditation of private companies with state responsibilities - and finally, also questions of representation, such as imaging techniques in luggage checks, radar appliances, mapping techniques, or oracles.

What these routines and practices do, first of all, is to produce and institutionalize a pattern of identification of threats to security with the aim to control these threats. ${ }^{121}$ Security routines aim at reconnaissance, be it the spotting of potential aggressors across fortification walls, satellite-supported surveillance of air space over state territory, or security checks at air-

\section{Cf. Daase 2012.}

116 Leander 2010.

117 Leander 2010.

118 Rauer 2012.

119 Latour 1996.

120 Aradau 2010.

121 Cf. Leander 2010; Rauer 2012. 
ports. In all these cases potential threats have to be identified (through demanding a word of passage, through identification of an airborne vehicle, or through establishing a person's identity). The question is, thus, through which patterns of identification are security concerns translated into control practices, regardless of the question whether they deliver security. From a figuration-analytical perspective, such reconnaissance establishes a particular balance of power between a control routine and an actant subjected to control, within a wider figuration which determines the frame conditions of that balance (through informational processes, juridical competencies, technological infrastructure, etc.).

The power to securitize through routines and practices thus amounts to a pattern of identification which links an epistemic procedure with an epistemic object. ${ }^{122}$ This distinguishes the power to securitize from other kinds of power, for instance, from such in which power materializes in the capability to produce insecurity, uncertainty or ambivalence like secret service disinformation campaigns or military disruptive actions, or from such that already presuppose an accomplished identification. To stick with the three examples in the last paragraph, it is only after the identification of 'security threats' that hot pitch is spilled on aggressors, that interceptor aircraft attacks intrude on an enemy aircraft, or that a suspicious person is arrested. Although these practices undoubtedly fashion security-related aspects and thus belong to the overall figuration of securitization which may impact on the identification of threats to security, it is precisely for this reason that they do not refer, strictly speaking, to the creation of a pattern of identification as core component of the power to securitize. They are, rather, examples for the power of the provision of security, to which we will turn now.

Field 4 comprises the consequences of acts that aim at enhancing security. These regard, first of all, those individuals, groups and figurations that find themselves subjected to the identification and control practices characteristic of the power to securitize. According to Heinrich Popitz, they might be termed "power to act" (Aktionsmacht) and "instrumental power". 123 "Power to act" boils down to the ability to do harm to others. It is directly relevant for securitization through routines and practices, for instance, in order to eliminate a threat from an aggressor identified as such.

123 See Popitz 1992, pp. 23-27. 
"Instrumental power", however, involves a decision on the side of the subjected, who is confronted with the choice to comply with the dominant person's demands or to face negative sanctions. This aspect of the power of securitization thus involves the cooperation, if rudimentary and potentially ambivalent, of the subjected. With a view to securitization, an example might be the urging to reveal security-related information through threatening the subjected with torture.

However, the power of securitization manifests itself also through unintended consequences for the securitizing actors/actants arising from the pattern of identification on which the power of security is grounded. Patterns of identification might develop a technological path-dependency or institutional inertia that make it difficult to question and modify them. The deployment of imaging technologies at airports may incentivize the development of weapons or explosives that pass the technological check. Demands for cooperation between banks and security authorities regarding money laundering for terrorist purposes may result in an over-compliance of banks, reporting each and every transaction and thus producing data noise instead of information. ${ }^{124}$ Implementing satellite-supported reconnaissance devices for nuclear missile relocations may trigger camouflage innovation and thus accelerate the arms race. In principle, it is not implausible to assume that the power to securitize, in the sense of putting to work practices of identification of potential threats, spills over into a figuration, as discussed by Elias on the occasion of the Cold War, that tends to spiral out of the control of the actors involved. ${ }^{125}$

\section{Conclusion: Paradoxes of power in securitization}

If viewed from the perspective of balances of power in Elias's sense as proposed in this chapter, the main power dynamics unfolding in acts of securitization are those between the activation of securitization and its effects, that is, between the power to securitize and the power of securitization. More specifically, it has been argued that the power to securitize often results in a situation in which the power to engage in cooperative steering of a conflict situation is taken away from securitizing actors, so that

124 Amicelle 2011; Favarel-Garrigues et al. 2011.

125 Elias 1983. 
the consequences of their securitization may spiral out of cooperative control. In the case of acts that aim at representing an issue as relevant for security, securitizing actors may find themselves in a condition that leaves little maneuvering space for performing acts outside of the 'grammar of security' and the role scripts that come with it - not least because, under conditions of an effected scene of decision, the promise of more securitization may become a political asset. Consultations with those construed as a threat to security might thus seem to be the least promising option for staying in control, which significantly deteriorates securitizing actors' communicative options. In the case of acts that aim at maintaining or establishing security in a given political or societal field, the institutionalization of a pattern of identification of security threats may result in an institutional and technological path dependency which effectively silences those subjected to controls, thus establishing a most effective categorization of actant types into which those thus categorized can hardly intervene. Here, cooperation is reduced to compliance with the techniques of identification, thus cutting securitizing practices effectively off from learning potentials that might ensue from a more broadly conceived cooperation between those in control and those controlled.

Considering these arguments, it seems as if securitization is a zero-sum game - not because, as realist IR would have it, power gains for one unit cannot but result in horizontal power losses for another unit. Rather, securitization always comes at a cost, namely the cost of a significantly decreased capability to engage in (political) cooperation even among adversaries. The question whether this cost in fact fully annuls the 'advantages' brought about by securitization is a historical one, as it depends on the historical and temporal horizon one envisages. Short-term gains in the identification of threats to security might be levelled out by long-term restrictions in trying to find common agendas for cooperation benefitting all sides involved. It is, not least, this problématique that demands a historical and trans-epochal perspective in securitization studies. ${ }^{126}$

\section{References}

Abulof, Uriel (2014): Deep securitization and Israel's “demographic demon". International Political Sociology 8: 396-415.

126 Cf. Buzan/Wæver 2009; Conze 2012. 
Amicelle, Anthony (2011): Towards a 'new' political anatomy of financial surveillance. Security Dialogue 42(2): 143-160.

Aradau, Claudia (2010): Security that matters: Critical infrastructure and objects of protection. Security Dialogue 41(5): 491-514.

Arendt, Hannah (2006): On Revolution. Introduction by Jonathan Schell. New York: Penguin.

Austin, John L. (1976): How to Do Things with Words. Oxford: Oxford University Press.

Bachmann-Medick, Doris (2010): Cultural Turns. New Orientations in the Study of Culture. Berlin: de Gruyter.

Bal, Mieke (2009): Narratology: Introduction to the Theory of Narrative. Toronto et al.: Toronto University Press.

Balzacq, Thierry (2005): The three faces of securitization: political agency, audience and context. European Journal of International relations 11(2): 171-201.

Balzacq, Thierry (2011): A theory of securitization: Origins, core assumptions, and variants. In: Thierry Balzacq (ed.): Securitization Theory: How Security Problems Emerge and Dissolve. London/New York: Routledge, pp. 1-30.

Balzacq, Thierry / Léonard, Sarah / Ruzicka, Jan (2016): 'Securitization revisited: Theory and cases. International Relations 30(4): 494-531.

Barnard-Wills, David / Ashenden, Debi (2012): Securing virtual space: Cyber war, cyber terror, and risk. Space and Culture 20(10): 1-14.

Bigo, Didier (2000): When two become one: Internal and external securitizations in Europe. In: Morten Klestrup / Michael C. Williams (eds.): International Relations Theory and the Politics of European Integration: Power, Security and Community. London: Routledge, pp. 142-148

Bigo, Didier (2006): Globalized-in-security: The field and the ban-opticon. In: Naoki Sakai/Jon Solomon (eds.): Translation, Biopolitics, Colonial Difference (= Traces. A Multilingual Series of Cultural Theory and Translation, vol 4.). Hong Kong: Hong Kong University Press, pp. 109-155.

Bigo, Didier (2014) Security, IR and anthropology: Encounters, misunderstanding and possible collaborations. In: Catarina Frois / Mark Maguire / Nils Zurawski (eds.): The Anthropology of Security. Basingstoke: Palgrave Macmillan, pp. 189-205.

Bonacker, Thorsten / Bernhardt, Jan (2003): Von der security community zur securitized community: Zur Diskursanalyse von Versicherheitlichungsprozessen am Beispiel der Konstruktion einer europäischen Identität. In: Alexander Siedschlag (ed.): Methoden der sicherheitspolitischen Analyse. Eine Einführung. Wiesbaden: Springer VS, pp. 219-242.

Booth, Ken (1991): Security and emancipation. Review of International Studies 17(4): 313-326.

Booth, Ken (2007): Theory of World Security. Cambridge: Cambridge University Press.

Bourdieu, Pierre (1990): The Logic of Practice. Cambridge: Polity Press. 
Bröckling, Ulrich (2012): Dispositive der Vorbeugung: Gefahrenabwehr, Resilienz, Precaution. In: Christopher Daase/Philipp Offermann/Valentin Rauer (eds.): Sicherheitskultur. Soziale und politische Praktiken der Gefahrenabwehr. Frankfurt a.M./New York: Campus, pp. 93-108.

Buzan, Barry/Wæver, Ole/de Wilde, Jaap (1998): Security: A New Framework for Analysis. Boulder, CO: Lynne Rienner.

Buzan, Barry/Wæver, Ole (2009): Macrosecuritisation and security constellations: Reconsidering scale in securitisation theory. Review of International Studies 35: 253276.

Buzan, Barry (2016): The English School: A neglected approach to International Security Studies. Security Dialogue 46(2): 126-143.

Conze, Eckart (2012): Securitization. Gegenwartsdiagnose oder historischer Analyseansatz? Geschichte und Gesellschaft 38: 453-467.

Daase, Christopher (2011): Sicherheitskultur - Ein Konzept zur interdisziplinären Erforschung politischen und sozialen Wandels. Sicherheit und Frieden / Security and Peace 29(2): 59-65.

Daase, Christopher (2012): Sicherheitskultur als interdisziplinäres Forschungsprogramm. In: Christopher Daase/Philipp Offermann/Valentin Rauer (eds.): Sicherheitskultur. Soziale und politische Praktiken der Gefahrenabwehr. Frankfurt a.M./New York: Campus, pp. 23-44.

Dahrendorf, Ralf (1965): Homo Sociologicus: Ein Versuch zur Geschichte, Bedeutung und Kritik der Kategorie der sozialen Rolle. Vierte Auflage. Köln/Opladen: Westdeutscher Verlag.

Der Derian, James (1995): The value of security: Hobbes, Marx, Nietzsche, and Baudrillard. In: Ronnie D. Lipschutz (ed.): On Security. New York: Columbia University Press, pp. 24-45.

Deutsch, Karl W. (1954 [1970]): Political Community at the International Level: Problems of Definition and Measurement. New York: Archon Books.

Dubiel, Helmut (1999): Integration durch Konflikt, in: Jürgen Friedrichs / Wolfgang Jagodzinski (eds.), Soziale Integration. (= Kölner Zeitschrift für Soziologie und Sozialpsychologie, Sonderheft 39.) Opladen: Westdeutscher Verlag, pp. 132-143.

Duindam, Jeroen (1998): Norbert Elias und der frühneuzeitliche Hof. Versuch einer Kritik und Weiterführung. Historische Anthropologie 3: 370-387.

Elias, Norbert (1969): Die höfische Gesellschaft. Darmstadt/Neuwied: Luchterhand.

Elias, Norbert (1976a [1969]): Über den Prozeß der Zivilisation. Soziogenetische und phylogenetische Untersuchungen. Erster Band: Wandlungen des Verhaltens in den weltlichen Oberschichten des Abendlandes. Frankfurt a.M.: Suhrkamp.

Elias, Norbert (1976b [1969]): Über den Prozeß der Zivilisation. Soziogenetische und phylogenetische Untersuchungen. Zweiter Band: Wandlungen der Gesellschaft / Entwurf zu einer Theorie der Zivilisation. Frankfurt a.M.: Suhrkamp.

Elias, Norbert (1983): Die Fischer im Mahlstrom. In: Engagement und Distanzierung. Arbeiten zur Wissenssoziologie I. Frankfurt a.M.: Suhrkamp, pp. 73-183. 
Elias, Norbert (2005 [1989]): Studien über die Deutschen. Machtkämpfe und Habitusentwicklung im 19. und 20. Jahrhundert. (= Gesammelte Schriften, Band 11.) Frankfurt a.M.: Suhrkamp.

Elias, Norbert (2006 [1986]): Wandlungen der Machtbalance zwischen den Geschlechtern. Eine prozeßsoziologische Untersuchung am Beispiel des antiken Römerstaats. In: Aufsätze und andere Schriften III. (= Gesammelte Werke, Band 16.) Frankfurt a.M.: Suhrkamp, pp. 139-181.

Favarel-Garrigues, Gilles / Godefroy, Thierry / Lascoumes, Pierre (2011): Reluctant partners? Banks in the fight against money laundering and terrorism financing in France. Security Dialogue 42(2): 179-196.

Foucault, Michel (1969): L'archéologie du savoir. Paris: Gallimard.

Foucault, Michel (2007): Security, Territory, Population. Lectures at the Collège de France 1977-1978. New York: Picador/Palgrave.

Frevel, Bernhard/Schulze, Verena (2012): Kooperative Sicherheitspolitik - Safety und Security Governance in Zeiten sich wandelnder Sicherheitskultur. In: Christopher Daase/Philipp Offermann/Valentin Rauer (eds.): Sicherheitskultur. Soziale und politische Praktiken der Gefahrenabwehr. Frankfurt a.M./New York: Campus, pp. 205225.

Guzzini, Stefano (2015): A Dual History of ,Securitisation: (= DIIS Working Paper 2015: 02.) Copenhagen: Danish Institute for International Studies.

Habermas, Jürgen (1987): Theory of Communicative Action, vol. 2: Lifeworld and System: A Critique of Functionalist Reason. Boston: Beacon Press.

Hagmann, Jonas / Dunn Cavelty, Myriam (2012): National risk registers: Security scientism and the propagation of permanent insecurity. Security Dialogue 43(1): 7996.

Hansen, Lene/Nissenbaum, Helen (2009): Digital disaster, cyber security, and the Copenhagen School. International Studies Quarterly 53: 1155-1175.

Hansen, Lene (2011): Theorizing the image for Security Studies: Visual securitization and the Muhammad Cartoon Crisis. European Journal of International Relations 17(1): 51-74.

Hansen, Lene (2012): Reconstructing desecuritisation: The normative-political in the Copenhagen School and directions for how to apply it. Review of International Studies 38: 525-546.

Huntington, Samuel P. (1994): The Clash of Civilizations and the Remaking of World Order. New York: Simon \& Schuster.

Huysmans, Jef (1998): Security! What do you mean? From concept to thick signifier. European Journal of International Relations 4(2): 226-255.

Huysmans, Jef (2006): International politics of insecurity: Normativity, inwardness and the exception. Security Dialogue 37(1): 11-29.

Huysmans, Jef (2006a): The Politics of Insecurity: Fear, Migration and Asylum in the $E U$. London/New York: Routledge.

Jahn, Egbert (2012): Frieden und Konflikt. Berlin: Springer. 
Kirchgässner, Gebhard (2008): Homo oeconomicus. Das ökonomische Modell invididuellen Verhaltens und seine Anwendung in den Wirtschafts- und Sozialwissenschaften. 3., ergänzte und erweiterte Auflage. Tübingen: Mohr Siebeck.

Langenohl, Andreas (2017): Securities markets and political securitization: The case of the sovereign debt crisis in the Eurozone. Security Dialogue 48(2): 131-148.

Latour, Bruno (1996): On Interobjectivity. In: Mind, Culture, and Activity 3(4): 228245.

Latour, Bruno (2000): When Things Strike Back: A Possible Contribution of 'Science Studies' to the Social Sciences. In: British Journal of Sociology 51(1): 107-123.

Leander, Anna (2010): Commercial security practices. In: J. Peter Burgess (ed.): The Routledge Handbook of New Security Studies. London/New York: Routledge, pp. 208-216.

Lipschutz, Ronnie D. (1995): On security. In: Ronnie D. Lipschutz (ed.): On Security. New York: Columbia University Press, pp. 1-23.

Munster, Rens van (2005): Logics of Security: The Copenhagen School, Risk Management and the War on Terror. Syddansk Universitet: Political Science Publications $10,2005$.

Popitz, Heinrich (1992): Phänomene der Macht. 2., stark erw. Auflage. Tübingen: Mohr (Siebeck).

Rauer, Valentin (2012): Interobjektivität: Sicherheitskultur aus Sicht der Akteur-Netzwerk-Theorie. In: Christopher Daase/Philipp Offermann/Valentin Rauer (eds.): Sicherheitskultur. Soziale und politische Praktiken der Gefahrenabwehr. Frankfurt a.M./New York: Campus, pp. 69-91.

Rheinberger, Hans-Jörg (1997): Toward a History of Epistemic Things: Synthesizing Proteins in the Test Tube. Stanford, California: Stanford University Press.

Salter, Mark B. (2008): Securitization and desecuritization: A dramaturgical analysis of the Canadian Air Transport Security Authority. Journal of International Relations and Development 11(4): 321-349.

Schmitt, Carl (1934): Politische Theologie: Vier Kapitel zur Lehre von der Souveränität. Berlin: Duncker \& Humblot.

Senn, Martin (2016): The art of constructing (in)security: Probing rhetorical strategies of securitization. Journal of International Relations and Development 20(3): DOI:10.1057/jird.2016.7.

Simmel, Georg (1989): Soziologie. Untersuchungen über die Formen der Vergesellschaftung. Frankfurt a.M.: Suhrkamp.

Stritzel, Holger (2012): Securitization, power, intertextuality: Discourse theory and the translations of organized crime. Security Dialogue 43(6): 549-567.

Tarde, Gabriel (1894): La sociologie élémentaire. Annales de l'Institut International de Sociologie 1, 209-234.

Vuori, Juha A. (2011): How to Do Security with Words: A Grammar of Securitization in the People's Republic of China. (= Annales Universitatis Turkuensis, Sarja - Ser. B OSA - tomus 336 - Humaniora.) Turku: University of Turku. 
Wæver, Ole (1995): Securitization and desecuritization. In: Ronnie D. Lipschutz (ed.): On Security. New York: Columbia University Press, pp. 46-86.

Wæver, Ole (1996): European security identities. Journal of Common Market Studies 34(1): 103-132.

Wæver, Ole (2000): The EU as a security actor: Reflections from a pessimistic constructivist on post-sovereign security orders. In: Morten Kelstrup, Michael C. Williams (eds.): International Relations Theory and the Politics of European Integration: Power, Security and Community. London: Routledge, pp. 250-294.

Wæver, Ole (2004): Aberystwyth, Paris, Copenhagen: New 'Schools' in Security Theo$r y$ and their Origins between Core and Periphery. Paper presented at the annual meeting of the International Studies Association, Montreal, March 17-20, 2004.

Wæver, Ole (2015): The history and social structure of security studies as a practicoacademic field. In: Trine Villumsen Berling / Christian Bueger (eds.): Security Expertise: Practice, Power, Responsibility. London / New York: Routledge, pp. 76106.

Weber-Mosdorf, Susanne (2013): Lassen sich globale Gesundheitsrisiken regulieren? Wirksamkeit und Grenzen internationaler Sicherheitsvorschriften. In: Christopher Daase/Stefan Engert/Julian Junk (eds.): Verunsicherte Gesellschaft - überforderter Staat: Zum Wandel der Sicherheitskultur. Frankfurt a.M./New York: Campus, pp. 153-167.

Williams, Michael C. (2003): Words, images, enemies: Securitization and international politics. International Studies Quarterly 47: 511-531.

Wyn Jones, Richard (2005): On emancipation, necessity, capacity and concrete utopias. In: Ken Booth (ed.): Critical Security Studies and World Politics. Boulder, CO: Lynne Rienner, pp. 215-235. 